Research Article

\title{
A study to evaluate and compare the anti-inflammatory activity of ethanolic and aqueous extract of Holoptelea integrifolia leaves on acute inflammatory models
}

\author{
Pramod S. G. ${ }^{*}$, Jayanthi M. K. ${ }^{2}$, Reddy Prasad C. ${ }^{3}$
}

\begin{abstract}
${ }^{1}$ Department of Pharmacology, DM-Wayanad institute of medical sciences, Wayanad, Kerala, India

${ }^{2}$ Department of Pharmacology, JSS medical college, Mysore, Karnataka, India

${ }^{3}$ Dept of Pharmacology, MVJ medical college, Bangalore, Karnataka, India
\end{abstract}

Received: 09 August 2016

Accepted: 16 August 2016

\section{*Correspondence to: \\ Dr. Pramod S.G, \\ Email:pammyson1985 \\ @ gmail.com}

Copyright: (C) the author(s), publisher and licensee Medip Academy. This is an openaccess article distributed under the terms of the Creative Commons Attribution NonCommercial License, which permits unrestricted noncommercial use, distribution, and reproduction in any medium, provided the original work is properly cited.

\begin{abstract}
Background: Inflammation is a local response of living mammalian tissues to injury. It is a body defence reaction in order to eliminate or to limit the spread of injurious agent. This study was intended to evaluate the anti-inflammatory activity of aqueous and ethanolic extract of Holoptelea intergifolia leaves.

Methods: The anti-inflammatory activity study was carried out by using Carrageenan induced rat paw oedema animal model and turpentine induced arthritis animal model. Wistar rats were divided into six groups of six animals each. Two different doses $(250 \mathrm{mg} / \mathrm{kg}$ and $500 \mathrm{mg} / \mathrm{kg}$ ) of aqueous and ethanolic extract of Holoptelea intergifolia leaves were given to the four different test group animals and compared with the standard drug indomethacin $(10 \mathrm{mg} / \mathrm{kg})$.

Results: In the present study both the extract exhibited significant Antiinflammatory activity. But, ethanolic extract has showed considerabely better values than aqueous extract which supports the traditional medicinal utilization of the plant.

Conclusions: Both the aqueous and ethanolic extract of Holoptelea Integrifolia leaves exihibited significant anti-inflammatory activity. But, Ethanolic extract had showed better results. Further studies involving the purification of the chemical constituents of the plant and the investigations in the biochemical pathways may result in the development of a potent anti-inflammatory agent with low toxicity and better therapeutic index.
\end{abstract}

Keywords: Holoptelea integrifolia, Aqueous extract, Ethanolic extract, Indomethacin, Inflammation

\section{INTRODUCTION}

Inflammation is a local response of living mammalian tissues to injury. It is a body defence reaction in order to eliminate or to limit the spread of injurious agent. There are various components to an inflammatory reaction that can contribute to the associated symptoms and tissue injury. Oedema formation, leukocyte infiltration and granuloma formation represent such components of inflammation. ${ }^{1}$ Although several agents are known to treat inflammatory disorders, their prolonged use often leads to gastric intolerance, bone marrow depression, water and salt retention. ${ }^{2}$ Hence the search for a new antiinflammatory drug of plant origin was made with low side effects. Holoptelea integrifolia belongs to the family Ulmaceac, having 15 genera and about 200 species, distributed over tropical and temperate regions of Northern hemisphere including Indian peninsula to IndoChina and Srilanka. ${ }^{3}$ The common vernacular names of the plant in India are Chirabilva, Putigandha (Sanskrit), Kanju, Papri, Banchilla, Chilbil, Dhamna, Begana (Hindi), Thavasai, Rasbija, Kaladri, Nilavahi (Kannada). ${ }^{4}$ It is commonly known as Indian Elm Tree. Holoptelea integrifolia is a large deciduous tree distributed 
throughout the greater part of India up to an altitude of 2,000 feet. It is an important pollen allergen plant of India. ${ }^{5}$ The plant Holoptelea integrifolia is used traditionally for the treatment of inflammation, gastritis, dyspepsia, colic, intestinal worms, vomiting, wound healing, leprosy, diabetes, hemorrhoids, dysmenorrhoea and rheumatism. ${ }^{6}$ Bark and leaves are used as bitter, astringent, thermogenic, anti-inflammatory, digestive, carminative, laxative, anthelmintic, depurative, repulsive, urinary astringent and in rheumatism. ${ }^{7}$

\section{METHODS}

\section{Collection of plant}

The plant material (Leaves of Holoptelea integrifolia) was collected from ODP campus, Bannimantap, Mysore, Karnataka, India and was authenticated by Dr. K. Mruthunjaya, Associate Professor, Dept of Pharmacognosy, JSSCP, Mysore. The Leaves of plant were cleaned to remove impurities and shade dried. The coarsely powdered leaves were weighed and stored in air tight containers.

\section{Preparation of ethanolic extract}

The coarsely powdered shade dried leaves of the plant Holoptelea integrifolia (200g) was extracted with ethanol by soxhlet extraction method for 25 hour. After completion of extraction the extract was filterd, concentrated using flash rotator evaporator and dried under vaccum.

\section{Preparation of aqueous extract}

The coarsely powdered shade dried leaves of the plant Holoptelea integrifolia (200 g) was macerated with chloroform: water $(5: 95)$ by cold maceration process for 3 days. After completion of extraction the marc was filtered through muslin cloth followed by filter paper and concentrated and dried on water bath to obtain aqueous extract of Holoptelea integrifolia and the extract was preserved in a refrigerator.

\section{Animals}

The experiments were carried out on adult Wistar albino rats weighing around $175 \pm 25 \mathrm{gm}$. Animals used in the study were procured from a registered breeder. The animal care and handling was carried out in accordance to guidelines issued by the Institutional Animal Ethics Committee, JSS Medical College, Mysore, and Karnataka. Animals were acclimatized to the experimental room for one week prior to the experiment. Animals were maintained under controlled conditions of temperature $\left(23 \pm 30^{\circ} \mathrm{C}\right)$ and humidity $(50 \pm 5 \%)$ and were caged in sterile polypropylene cages containing sterile paddy husk as bedding material with maximum of four animals in each cage. The mice were fed on standard food pellets and water ad-libitum. The studies conducted were approved by the Institutional Ethical Committee, JSS Medical College, Mysore, Karnataka.

Inclusion criteria: Rats of either sex weighing $175 \pm 25 \mathrm{gm}$.

Exclusion criteria: Pregnant and Diseased animals are not included in this study.

Chemicals used: Indomethacin $(10 \mathrm{mg} / \mathrm{kg})$ of body weight, Carrageenan (1\%), Turpentine (1\%), Ether and ethanol.

Instruments required: Mercury plethsmograph, screwgauge, feeding tube, tuberculin syringe, mouth gag.

\section{Models of experiment}

The animals were randomly divided into 6 groups of 6 each. Group-I served as Control and received 2\% gum acacia suspension orally (without drug). Group-II served as standard, received indomethacin $10 \mathrm{mg} / \mathrm{kg}$ of body weight, per oral. Group III and IV served as test, received Aqueous extract (HIAQ) at doses of 250 and $500 \mathrm{mg} / \mathrm{kg}$ of body weight, (per oral), respectively. Group V and VI served as test, received ethanolic extract (HIAL) at doses of 250 and $500 \mathrm{mg} / \mathrm{kg}$ of body weight, (per oral), respectively. Each rat was fed with respective drug one hour prior to the administration of phlogestic agent.

\section{Carrageenan induced rat paw oedema animal model ${ }^{8}$}

$0.1 \mathrm{ml}$ of $1 \%$ carrageenan was injected into the subplantar surface of right hind paw of each group. Paw volume was measured by mercury plethysmograph at ' 0 'hour and at the end of ' 4 ' hours. The difference between the zero and 4 hours gave the actual oedema. From the mean paw oedema volume the percentage inhibition of oedema was calculated between the test, standard and the control group.

\section{Turpentine induced arthritis animal model ${ }^{9}$}

$0.1 \mathrm{ml}$ of turpentine oil was injected into the right knee joint of each rat. Then the lateral diameter was measured by screw gauge at ' 0 ' hour and at the end of ' 4 ' hours. Change in lateral diameter was noted. From the mean difference in lateral diameter and the percentage of inhibition of arthritis was calculated between the test, standard and the control group.

\section{RESULTS}

\section{Statistical methods applied}

The effect of aqueous and ethanolic extract of Holoptelea-integrifolia leaves was presented by calculating Mean and SD of the outcome parameters. One way ANOVA and Post hoc test was applied to see the differences between any two groups at a time. Test of 
significance were carried out at 5\% level. SPSS for windows (version 21) was applied in the statistical analysis.

The aqueous and ethanolic extract of Holoptelea integrifolia leaves have been investigated in this study for their anti-inflammatory potential and compared with the standard reference drug Indomethacin. In the present study the acute experimental inflammatory models studied includes, Carrageenan induced rat paw oedema and Turpentine induced arthritis model.

In both the experimental inflammatory models, Indomethacin was used as Standard drug and Aqueous and ethanolic extract of Holoptelea integrifolia leaves was used as test drug.

Table 1: The mean rat paw volume (cms) at 0 hour and 4 hour and difference between the groups.

\begin{tabular}{|c|c|c|c|c|c|c|c|c|}
\hline Groups & $\begin{array}{l}0 \text { hour } \\
\text { Mean } \pm \text { SD }\end{array}$ & $\begin{array}{l}\text { hour } \\
\text { Mean } \pm \text { SD }\end{array}$ & $\begin{array}{l}\text { Mean } \\
\text { difference } \\
\text { in paw } \\
\text { edema }(\mathrm{cms})\end{array}$ & ANOVA & $\begin{array}{l}\text { Mean } \\
\text { difference } \\
\text { in paw } \\
\text { edema of } \\
\text { test and } \\
\text { STD with } \\
\text { respect to } \\
\text { control }\end{array}$ & $\begin{array}{l}\% \text { of } \\
\text { inhibition } \\
\text { in paw } \\
\text { edema of } \\
\text { test and } \\
\text { STD with } \\
\text { respect to } \\
\text { control }\end{array}$ & $\begin{array}{l}\text { Mean } \\
\text { difference } \\
\text { in paw } \\
\text { edema of } \\
\text { test with } \\
\text { respect to } \\
\text { STD }\end{array}$ & $\begin{array}{l}\% \text { of } \\
\text { inhibition } \\
\text { in paw } \\
\text { edema of } \\
\text { test with } \\
\text { respect to } \\
\text { STD }\end{array}$ \\
\hline Control & $1.33 \pm 0.14$ & $8.49 \pm 0.8$ & 7.16 & \multirow{6}{*}{$\begin{array}{l}F=40.26 \\
P=0.001\end{array}$} & - & - & - & - \\
\hline Standard & $1.28 \pm 0.17$ & $3.83 \pm 0.63$ & 2.545 & & 4.62 & $64.45 \%$ & - & - \\
\hline HIAQ250 & $1.24 \pm 0.13$ & $6.51 \pm 0.64$ & 5.262 & & 1.9 & $26.5 \%$ & 2.72 & $41.12 \%$ \\
\hline HIAQ500 & $1.28 \pm 0.13$ & $5.74 \pm 0.46$ & 4.46 & & 2.7 & $37.7 \%$ & 1.92 & $58.44 \%$ \\
\hline HIAL250 & $1.27 \pm 0.15$ & $5.41 \pm 0.81$ & 4.134 & & 3.03 & $42.26 \%$ & 1.59 & $65.58 \%$ \\
\hline HIAL500 & $1.29 \pm 0.10$ & $4.29 \pm 0.39$ & 2.995 & & 4.17 & $58.24 \%$ & 0.45 & $90 \%$ \\
\hline
\end{tabular}

Table 2: The mean lateral knee diameter $(\mathrm{mm})$ at 0 hour and 4 hour and difference between the groups.

\begin{tabular}{|c|c|c|c|c|c|c|c|c|}
\hline Groups & $\begin{array}{l}0 \text { hour } \\
\text { Mean } \pm \text { SD }\end{array}$ & $\begin{array}{l}4 \text { hour } \\
\text { Mean } \pm \text { SD }\end{array}$ & $\begin{array}{l}\text { Mean } \\
\text { difference } \\
\text { in paw } \\
\text { edema }(\mathrm{cms})\end{array}$ & ANOVA & $\begin{array}{l}\text { Mean } \\
\text { difference } \\
\text { in paw } \\
\text { edema of } \\
\text { test and } \\
\text { STD with } \\
\text { respect to } \\
\text { control }\end{array}$ & $\begin{array}{l}\% \text { of } \\
\text { inhibition } \\
\text { in paw } \\
\text { edema of } \\
\text { test and } \\
\text { STD with } \\
\text { respect to } \\
\text { control }\end{array}$ & $\begin{array}{l}\text { Mean } \\
\text { difference } \\
\text { in paw } \\
\text { edema of } \\
\text { test with } \\
\text { respect to } \\
\text { STD }\end{array}$ & $\begin{array}{l}\% \text { of } \\
\text { inhibition } \\
\text { in paw } \\
\text { edema of } \\
\text { test with } \\
\text { respect to } \\
\text { STD }\end{array}$ \\
\hline Control & $3.13 \pm 0.25$ & $9.46 \pm 0.52$ & 6.33 & \multirow{6}{*}{$\begin{array}{l}F=96.16 \\
P=0.001\end{array}$} & - & - & - & - \\
\hline Standard & $3.36 \pm 0.2$ & $4.98 \pm 0.35$ & 1.62 & & 4.71 & $74.4 \%$ & - & - \\
\hline HIAQ250 & $3.21 \pm 0.24$ & $7.75 \pm 0.31$ & 4.54 & & 1.79 & $28.27 \%$ & 2.92 & $38 \%$ \\
\hline HIAQ500 & $3.35 \pm 0.31$ & $6.88 \pm 0.33$ & 3.53 & & 2.8 & $44.23 \%$ & 1.91 & $59.44 \%$ \\
\hline HIAL 250 & $3.36 \pm 0.25$ & $6.65 \pm 0.42$ & 3.29 & & 3.04 & $48.02 \%$ & 1.67 & $64.54 \%$ \\
\hline HIAL500 & $3.36 \pm 0.12$ & $5.53 \pm 0.43$ & 2.17 & & 4.16 & $65.71 \%$ & 0.55 & $88.32 \%$ \\
\hline
\end{tabular}

The percentage inhibition of carageenan induced rat paw oedema by Indomethacin compared with control was $64.45 \%$ while that of HIAQ250, HIAQ500, HIAL250 and HIAL500 was $26.5 \%, 37.7 \%, 42.26 \%$ and $58.24 \%$ respectively. Hence the anti-oedema activity of both the aqueous and ethanolic extract was comparable with that of standard. But, in the present study ethanolic extract has shown more effective results than the aqueous extract. The percentage of inhibition of paw oedema by the HIAQ250, HIAQ500, HIAL250 and HIAL500 was $41.12 \%, 58.44 \%, 65.58 \%$ and $90 \%$, respectively, considering the percentage of inhibition of paw oedema activity by standard as $100 \%$.
This indicates that ethanolic extract has good antiinflammatory activity than the aqueous extract comparable with the potent standard drug indomethacin in carrageenan induced rat paw oedema model (Table 1) (Figure 1) (Figure 2).

The percentage inhibition of turpentine induced knee arthritis by standard (Indomethacin) compared with control was $74.4 \%$ and that of HIAQ250, HIAQ500, HIAL250 and HIAL500 was $28.27 \%, 44.23 \%, 48.02 \%$ and $65.71 \%$ respectively. Thus both the aqueous and ethanolic extract showed moderately good anti-arthritic activity as compared to the standard drug. The percentage inhibition of knee arthritis by the HIAQ250, HIAQ500, 
HIAL250 and HIAL500 was 38\%, 59.44\%, 64.54\% and $88.32 \%$ respectively, considering the percentage inhibition of arthritis by standard as $100 \%$. With this background both the aqueous and ethanolic extract showed moderate anti-inflammatory activity comparable with potent standard drug Indomethacin in Turpentine induced arthritis model. But, ethanolic extract has showed considerably better values than aqueous extract. (Table 2) (Figure 3) (Figure 4).

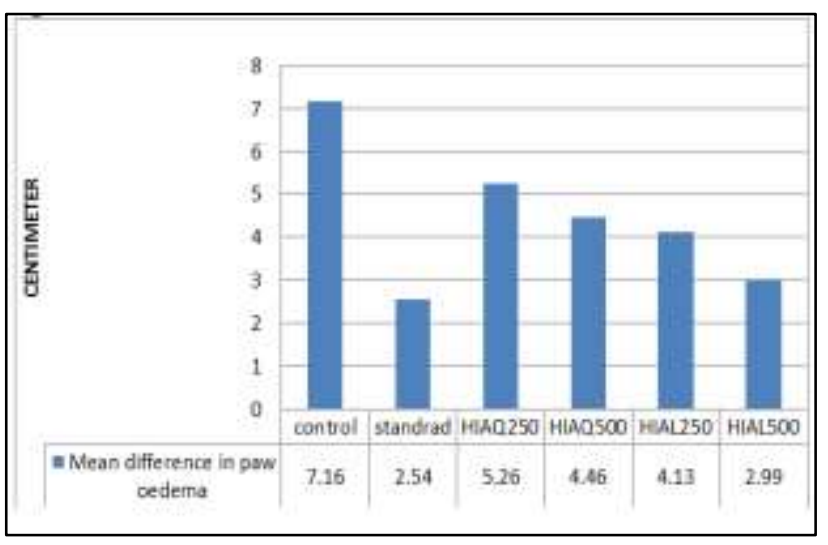

Figure 1: Mean difference in paw oedema.

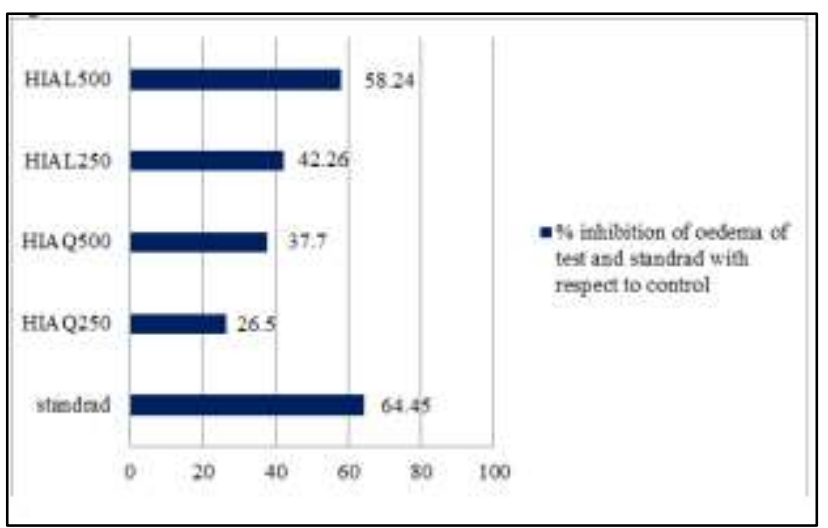

Figure 2: \% inhibition of paw oedema of test and standrad with respect to control.

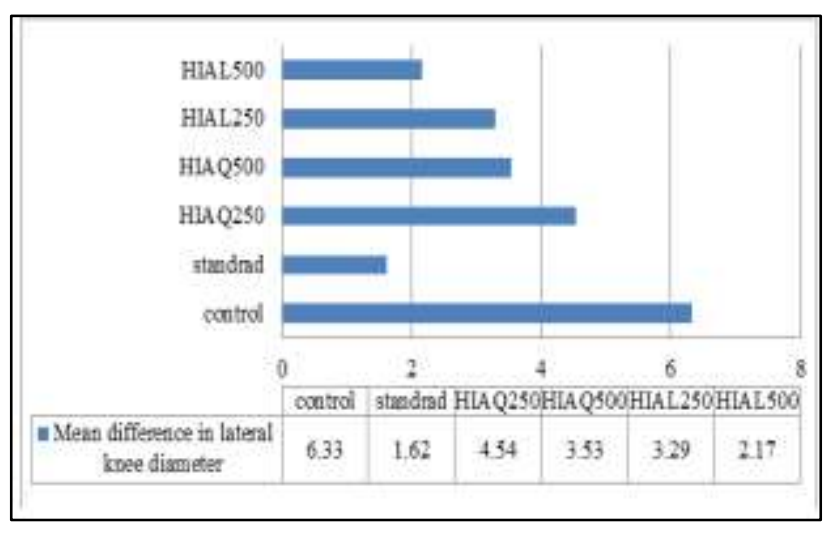

Figure 3: Mean difference in lateral knee diameter.

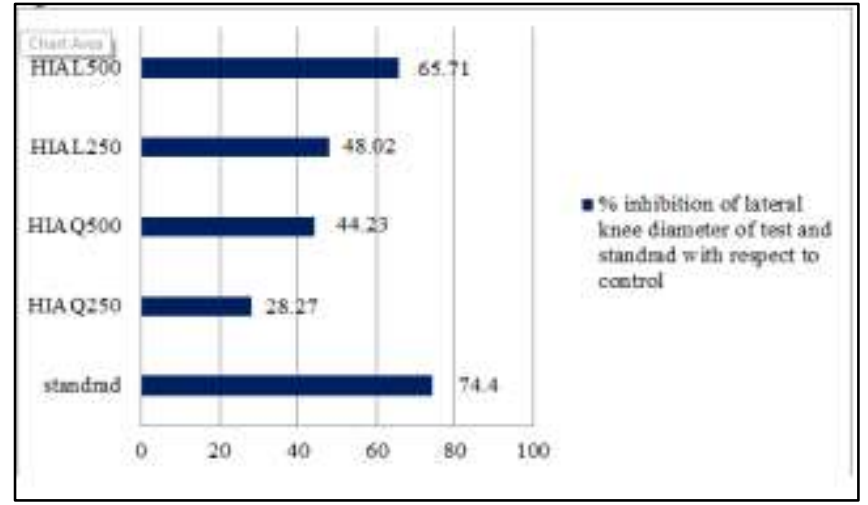

Figure 4: \% inhibition of lateral knee diameter of test and standrad with respect to control

\section{DISCUSSION}

Inflammation is a protective attempt by the organism to remove the injurious stimuli and to initiate the healing process. Inflammation can be classified as either acute or chronic. Acute inflammation is the initial response of the body to harmful stimuli and is achieved by the increased movement of plasma and leukocytes (especially granulocytes) from the blood into the injured tissues. A cascade of biochemical events propagates and matures the inflammatory response involving the local vascular system, the immune system and various cells within the injured tissue. Prolonged inflammation, known as chronic inflammation, leads to a progressive shift in the type of cells present at the site of inflammation and is characterized by simultaneous destruction and healing of the tissue from the inflammatory process. Antiinflammatory drugs inhibit different stages of inflammation.

Holoptelea integrifolia belongs to family ulmaceac, also known as indian elm tree. The plant is being used by tribal people for their medicinal properties. The bark and leaves of Holoptelea integrifolia is bitter, astringent, acrid, thermogenic, anti-inflammatory, digestive, carminative, laxative, antehelmintic, urinary astringent, and are used in inflammation, acid gastritis, dyspepsia, flatulence, intestinal colic, intestinal worms, vomiting, wound healing, skin disease, vitiligo, leprosy, filariasis, diabetes, haemorroids and in Rheumatism. ${ }^{10,11}$

Various studies have shown that aqueous and ethanolic extract of leaves of Holoptelea integrifolia planch possess significant anti-inflammatory effects in various animal models. A significant \% inhibition of paw edema by the aqueous extract of leaves of $H$. integrifolia Planch and it's almost nearby same \% inhibition with indomethacin suggest its usefulness as an antiinflammatory agent. ${ }^{12}$ The ethanolic extract of the leaves of Holoptelea integrifolia planch showed significant antiinflammatory effects in various animal models. Results revealed that administration of ethanolic extract inhibited the oedema starting from the first hour and during all 
phases of inflammation, which is probably inhibition of different aspects and chemical mediators of inflammation. ${ }^{13}$

The use of friedelin or friedelin-type compounds has been considered for treatment of convulsions, inflammation, topical ulcers, rheumatic inflammation, fever and dysentery. ${ }^{14,15}$ The leaves of Holoptelea integrifolia ethanolic extract showed the presence of terpenoid, steroids, tannins, saponins, carbohydrates and protein. 1,4-naphthalenedione has been isolated from leaves of Holoptelea integrifolia and is reported to possess antibacterial activity against Staphylocopccus aureus, hexacosanol, octacosanol, sitosterol, amyrin are isolated from leaves. ${ }^{16}$ The leaves contain friedelin or friedelintype compounds has been considered for treatment of cancer of bladder, convulsions, inflammation, topical ulcers, rheumatic inflammation, fever and dysentery. ${ }^{17}$

In the present study using carageenan induced rat paw oedema model and turpentine induced knee arthritis both aqueous and ethanolic extract of leaves of Holoptelea integrifolia has shown significant anti-oedema and antiarthritic activity as compared to that of standard drug indomethacin. But, ethanolic extract has good antiinflammatory activity than the aqueous extract. Hence ethanolic extract of leaves of Holoptelea integrifolia can be used to combat inflammation alone or with other conventional anti-inflammatory agents to treat various inflammatory disorders.

\section{CONCLUSION}

Thus, in the present study, both the aqueous and ethanolic extract of Holoptelea Integrifolia leaves showed that it possesses potent anti-inflammatory activities. But, Ethanolic extract had showed better results. Further studies involving the purification of the chemical constituents of the plant and the investigations in the biochemical pathways may result in the development of a potent anti-inflammatory agent with low toxicity and better therapeutic index.

Funding: No funding sources

Conflict of interest: None declared

Ethical approval: The study was approved by the Institutional Ethics Committee

\section{REFERENCES}

1. Mitchell RN, Cotran RS. In: Robinsons basic pathology, seventh ed., New Delhi, Harcourt (India) Pvt. Ltd; 2000:33.

2. Saxena RS, Gupta B, Saxena KK, Singh R, Prasad DN. Study of anti-inflammatory activity of the leaves of nyctanthes arbor-tristis Linn: An Indian Medicinal Plant. Journal of Ethno-pharmacology. 1987;11:319-30.
3. Mahmud S, Shareef HM, Ahmad S, Gouhar GH, Rizwani. Pharmacognostic studies on fresh leaves of Holoptelea integrifolia Roxb. Pakistan Journal of Botany. 2010;42:3705-708.

4. Acharya D. Monkey's favourite seasonal fruit: Holoptelea integrifolia. American Chronicle. 2008:1-5.

5. Singh AB, Kumar P. Aeroallergens in clinical Practice of allergy in India: an overview. Ann Agricul Environ Medicine. 2003;10:131-6.

6. Warrier PK, Nambiar VPK, Ramakutty C. Indian Medicinal Plants a compendium of 500 species. Orient longman private Limited; 1995;3:162.

7. Prajapati ND, Purohit SS, Sharma AK. A Handbook of Medicinal Plants a Complete Source Book. Agrobias India Jodhpur. 2003:273.

8. Winter CA, Risley EA. Carrageenan induced oedema in hind paw of the rat as an assay for antiinflammatory drugs. Proc soc Expt Biol (NY). 1962;111:544.

9. Teotino UM, Polofrig L, Gandini A. Antipyretic activity of thio derivative of 2,3 dihydro $4 \mathrm{H}-1,3$ Benzoxacin-4-1 synthesis and pharmacological property J Med Chem. 1963;6:2489.

10. Warrier PK, Nambiar VPK, Ramankutty. Indian Medicinal Plants: a Compendium of 500 Species. Chennai: Orient Longman Pvt Ltd; 2004;4:162.

11. Chopra RN, Chopra IC, Varma BS. Supplement to Glossary of Indian Medicinal Plants. New Delhi: CSIR. 1992:40.

12. Sharma S, Lakshmi KS, Patidar A, Chaudhary A, Dhaker S. Studies on anti-inflammatory effect of aqueous extract of leaves of Holoptelea integrifolia Planch in rats. Indian J Pharmacol. 2009;41:87-8.

13. Upadhyay KA. Anti-inflammatory evaluation of ethanolic extract of leaves of Holoptelea integrifolia, Planch. Scholars Research Library Annals of Biological Research. 2010;1:185-95.

14. Chaturvedi AK, Parmar SS, Bhatnagar SC, Mistra G, Nigam SK. Res Commun Chem Pathol Pharmacol. 1976;8:199-210.

15. Queiroga CL, Silva GF, Dias PC, Possenti A, de Carvalho JE. J Ethnopharmacol. 2000;72(3): 465-8.

16. Vinod NV, Shijina R, Dileep KV, Sadasivan C. Inhibition of Beta-Lactamase by 1,4Naphthalenedione from Holoptelea integrifolia. Applied biochemistry and biotechnology. 2010;160:1752-9.

17. Chandler RF, Hooper SN. Review: Friedelin and Associated Triterpenoids. Phytochemistry. 1979;18:711-24.

Cite this article as: Pramod SG, Jayanthi MK, Reddy CP. A study to evaluate and compare the anti-inflammatory activity of ethanolic and aqueous extract of Holoptelea integrifolia leaves on acute inflammatory models. Int J Basic Clin Pharmacol 2016;5:1780-4 